\title{
An end-to-end model to evaluate the sensitivity of ecosystem indicators to track fishing impacts
}

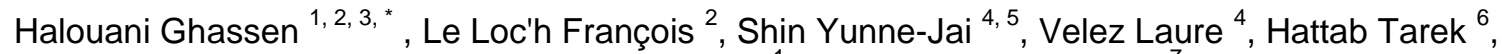 \\ Romdhane Mohamed Salah ${ }^{1}$, Ben Rais Lasram Frida ${ }^{7}$
}

${ }^{1}$ UR 03AGRO1 Ecosystèmes et Ressources Aquatiques, Institut National Agronomique de Tunisie, 43 Avenue Charles Nicolle, 1082 Tunis, Tunisia

${ }^{2}$ UMR 6539 Laboratoire des Sciences de I'Environnement Marin (CNRS, UBO, IRD, Ifremer), Institut Universitaire Européen de la Mer, Technopôle Brest-Iroise, Rue Dumont d'Urville, 29280 Plouzané, France

${ }^{3}$ Marine and Freshwater Research Centre (MFRC), Galway-Mayo Institute of Technology (GMIT), Dublin Road, Galway, Ireland

${ }^{4}$ MARBEC (IRD, Ifremer, Université de Montpellier, CNRS), Université de Montpellier, Bat. 24 - CC 093 Place Eugène, Bataillon 34095, Montpellier cedex 5, France

${ }^{5}$ University of Cape Town, Ma-Re Institute, Dept of Biological Sciences, Private Bag X3, Rondebosch 7701 , South Africa

${ }^{6}$ MARBEC (IRD, Ifremer, Université de Montpellier, CNRS), Centre Ifremer, Avenue Jean Monnet, CS 30171,34203 Sète Cedex, France

${ }^{7}$ Univ. Littoral Côte d'Opale, Univ. Lille, CNRS, UMR 8187, LOG, Laboratoire d'Océanologie et de Géosciences, F 62930 Wimereux, France

* Corresponding author : Halouani Ghassen, email address : ghassen.halouani@gmail.com

\begin{abstract}
:
In order to assist fisheries managers, ecological indicators are needed to evaluate the effects of fishing activities on marine ecosystems and to improve communication of these effects in both public and scientific contexts. Finding appropriate indicators is challenging given the complexity of marine food webs as well as the ecosystem response to fishing pressure. In this study, an end-to-end model developed in the Gulf of Gabes ecosystem (Tunisia) was used to compare the performance of a set of ecosystem indicators in assessing the impact of fishing. This end-to-end model aimed to represent the ecosystem functioning by coupling two existing sub-models, the multispecies individual-based model OSMOSE, representing the dynamics of exploited species and the biogeochemical model Eco3M-Med. The aim of the indicator selection method is to evaluate the sensitivity of a set of ecological indicators regardless the fishing management plan. This method was performed in two major steps. The first step consisted in simulating three simple contrasted fishing strategies in the OSMOSE model exploiting target species (i.e. high trophic level, low trophic level or all species) and then applying a fishing effort multiplier for each fishing strategy to the focus target species. In the second step, three paradigms defining the desirable properties of an ecological indicator have been specified: i/the indicator decreases with increasing fishing pressure, ii/the indicator responds linearly to an increase in fishing pressure and iii/the indicator responds consistently across different fishing strategies. Our results highlighted that the majority of indicators have quite similar performance regarding the trend and the linearity of their responses. However, the size-based indicators seem to be the most robust to track
\end{abstract}


ecosystem effects of fishing when the fishing strategy changes. A focus on size-based indicators showed that Large Fish Indicators $(40 \mathrm{~cm})$ derived from demersal or all surveyed species were the most suitable to reflect a change in the status of the Gulf of Gabes ecosystem due to fishing pressure.

\section{Graphical abstract}

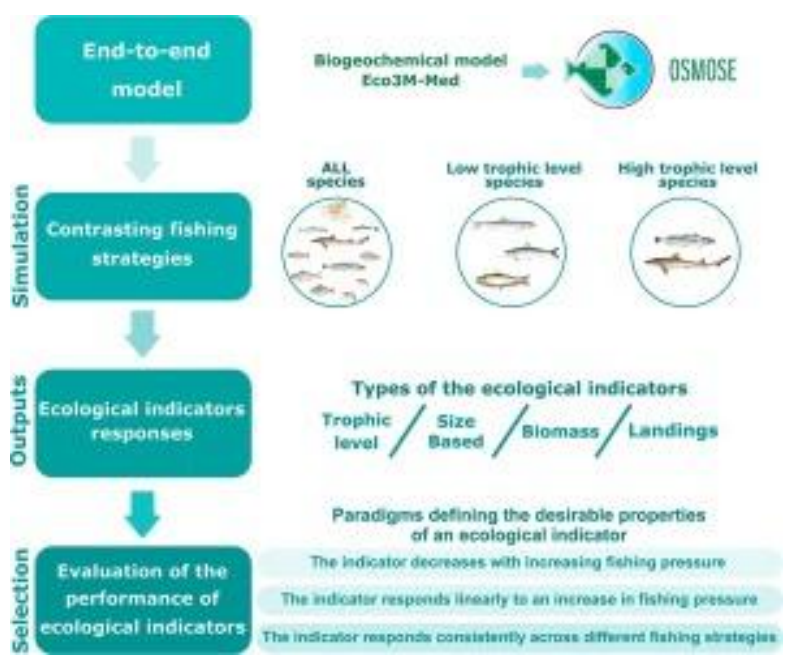

\section{Highlights}

- An end-to-end model was used to evaluate a set of indicators in the Gulf of Gabes. Contrasted fishing strategies were simulated to test the performance of indicators. The indicators were compared based on their sensitivity to fishing pressure. 3 paradigms defining the desirable properties of an indicator were scrutinized. The Large Fish Indicators were the most sensitive to track fishing effects.

Keywords : Ecological indicators, OSMOSE, Ecosystem model, End-to-end model, Marine ecosystem, Fishing impacts, Fishery, Gulf of Gabes 


\section{Introduction}

Fisheries resources are important sources of food, livelihoods and income for millions of people around the world especially in the developing countries which export more than half of fish by value (FAO, 2016). However, the increasing demand for fish products due to human population growth and globalization causes an intense pressure on marine resources. Overfishing combined to other sources of stress (e.g. pollution, habitat degradation, climate change, etc.) is likely to affect the ecosystem integrity and compromise the provision of ecosystem services (Jackson et al., 2001; Worm et al., 2006).

Over the past two decades, research organizations have focused on the need for a more holistic management approach to support the Ecosystem Approach to Fisheries (EAF) with the goal of promoting resource sustainability (Garcia, 2003; Plagányi et al., 2007). This approach aims to take into account both ecosystem complexity and the fishing activities in order to limit overfishing and the resulting depletion of fish stocks. To fulfill these objectives there is a need to provide sets of suitable ecological indicators that reflect the status of fisheries and the effects of fishing activities on marine ecosystems. The use of such indicators is essential to implement effective and precautionary fishing management plans (Coll et al., 2016; Shin et al., 2012, 2010). Several tools and frameworks have been developed by the scientific community to characterize ecosystem responses to fishing pressure and select a set of measurable indicators over contrasting conditions (Sasaki et al., 2015; Shin et al., 2018; Travers et al., 2006).

This study represents an application of an end-to-end model to perform a comparative analysis of ecological indicators in the Gulf of Gabes using the OSMOSE model (Object-oriented Simulator of Marine ecOSystem Exploitation) 
coupled to the biogeochemical model Eco3M-Med. The main objective of this work is to evaluate the response of a set of ecological indicators to different fishing mortalities and assess their sensitivity to track fishing pressure under different fishing strategies. The OSMOSE model was chosen because of its ability to consider the complexity and the high stochasticity of marine ecosystems, as well as the possibility to provide a great variety of ecological indicators in output, e.g., size-based, speciesbased, trophic indicators (Shin and Cury, 2004, 2001). The multispecies model OSMOSE is a spatial, age- and size-structured individual-based model (IBM). It explicitly accounts for ecological and biological processes at the individual level, considering whole-life cycle dynamics of marine organisms to simulate the functioning of marine food webs. Given the complexity of ecosystem attributes, this model can be used as a virtual laboratory to investigate fishing impacts at different biological organization levels.

The OSMOSE model has been applied in different marine ecosystems to model trophic structure/dynamics and to address several ecological and management questions. This study is based on the OSMOSE model OSMOSE-GoG developed in the coastal ecosystem of the Gulf of Gabes (Halouani et al., 2016). This ecosystem was historically managed with the objective of maximizing the landings of commercial species. However, given the expansion of the fishery and the increase of fishing effort, the first signs of overfishing appeared in the early 1990s. Hence, there is an interest from local policy-makers to track fishing impacts on the Gulf of Gabes ecosystem. 


\section{Material and methods}

2.1. Study area

The Gulf of Gabes is located off southern Tunisia in the South-central Mediterranean Sea and encompasses a total area of approximately $36,000 \mathrm{~km}^{2}$ (Fig. 1). Recognized as one of the most important fishing areas in Tunisia, the fishery is multispecies and multigears, landing up to more than 80 different species. This region has a large continental shelf, exclusively composed of soft sediment resulting in the prevalence of bottom trawling activities. Despite the oligotrophic conditions of the Mediterranean Sea, the Gulf of Gabes is one of the most productive ecosystems in the region (Papaconstantinou and Farrugio, 2000). The high level of productivity is partly due to the presence of the ecologically important endemic Mediterranean seagrass Posidonia Oceanica (Ben Mustapha and Afli, 2007; Zucchetta et al., 2016). The seagrass meadows provide an important nursery, feeding, and breeding ground for many exploited marine species (Hattour and Ben Mustapha, 2013). Furthermore, the ecosystem is under multiple anthropogenic threats and is subject to important changes on its biodiversity and functioning (Drira et al., 2016; Hattab et al., 2014; Lasram et al., 2015). 


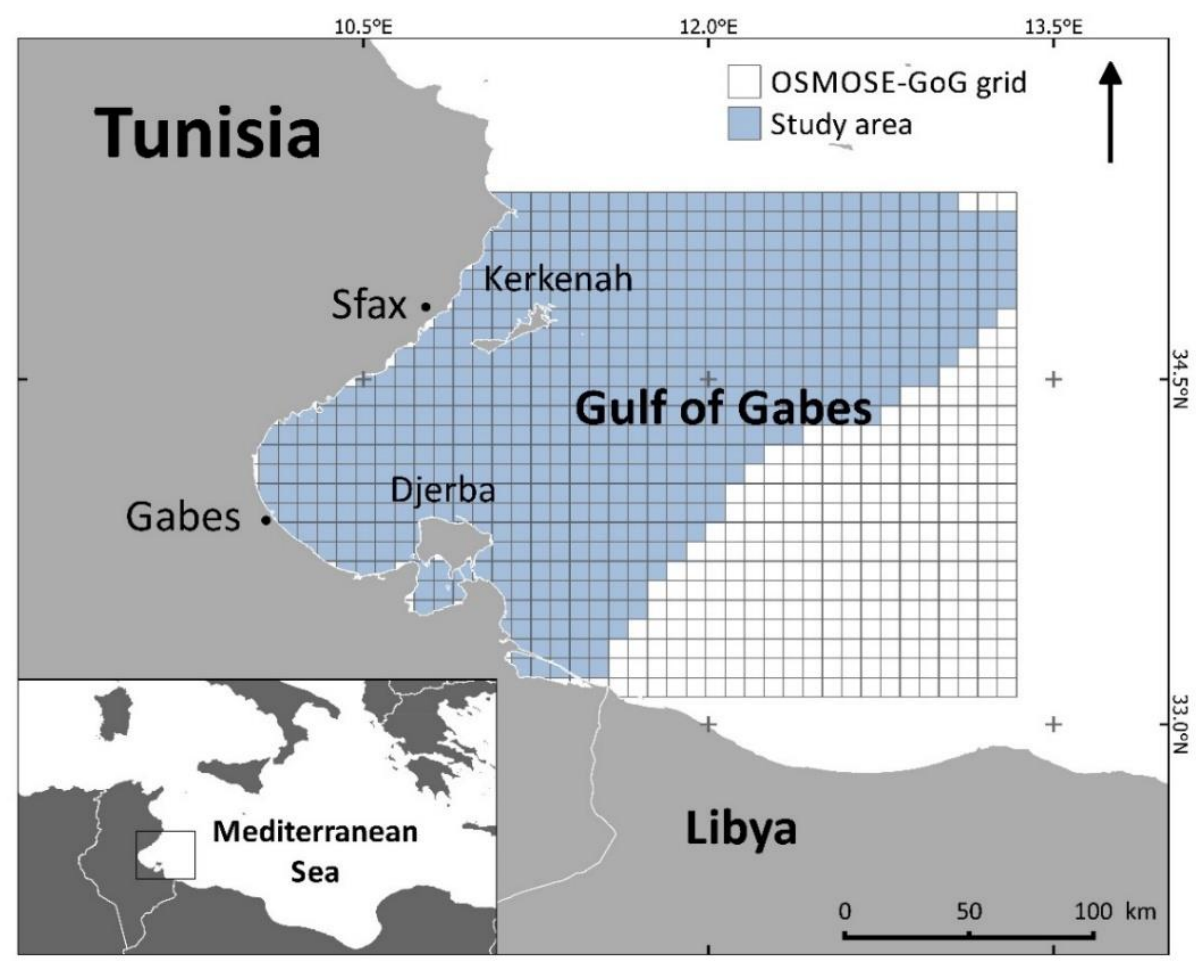

116 Fig. 1. Map of the Gulf of Gabes ecosystem model showing the spatial grid of

117 OSMOSE-GoG model (blue cells).

An end-to-end model has been developed in the Gulf of Gabes to represent the dynamics of 11 high trophic level species, from climate forcing to fishing, by integrating physical, biogeochemical and biological processes. This modelling approach consisted in forcing the individual-based model "OSMOSE" (Halouani et al., 2016; Shin and Cury, 2004) focused on high trophic levels species (HTL) by a biogeochemical model "ECO3M-Med" (Alekseenko et al., 2014; Guyennon et al., 2015) representing the low trophic level organism dynamics (LTL). The two sub-

127 models were linked through trophic interactions to characterize the food web

128 structure of the ecosystem from plankton up to top predators for the 2000 s period.

129 This link was established through opportunistic predation based on prey size 
selection and spatio-temporal co-occurrence between predators and their prey over space and time. The biomass fields of four planktonic groups (phytoplankton, nanozooplankton, microzooplankton, and mesozooplankton) obtained from the biogeochemical model and one benthos group were used as inputs for OSMOSE (one way coupling without any feedback). The distribution areas of HTL species obtained from multi-scale species distribution modelling (Hattab et al., 2014) were implemented in OSMOSE as a presence/absence map (Fig. 2). The end-to-end model presented in this paper is fully described in (Halouani et al., 2016). Thus, only a brief presentation of the model structure and parameterization is given in the present study.

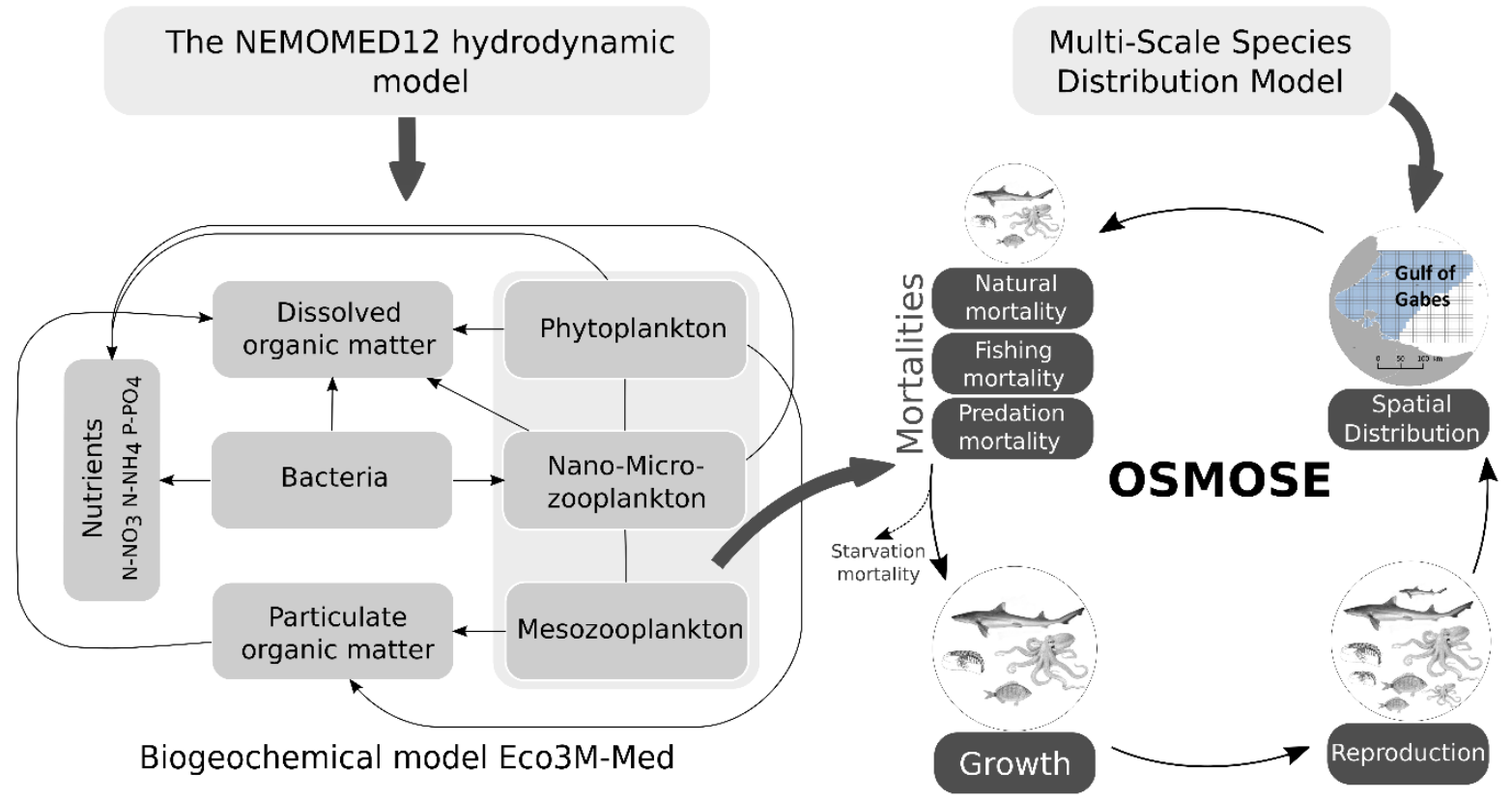

142 Fig. 2. Conceptual model of the one-way coupling between OSMOSE and Eco3MMED. OSMOSE species can prey upon both plankton and high trophic level species, 144 depending on predator/prey size ratios and spatio-temporal prey availability 145 (Halouani et al., 2016). 
OSMOSE-GoG is an application of OSMOSE in the continental shelf of the Gulf of Gabes, that is forced by the biogeochemical model Eco3M-Med to take into account the dynamics of planktonic groups for the period 2001-2010 (Halouani et al., 2016). The modelled area extends from the coastline to the isobath $200 \mathrm{~m}$ with a regular grid of 1040 cells of $0.08^{\circ} \times 0.08^{\circ}$ degree latitude/longitude and covering the geographical area from $\left(33.1^{\circ} \mathrm{N} / 35.3^{\circ} \mathrm{N}\right)$ to $\left(9.9^{\circ} \mathrm{E} / 13.3^{\circ} \mathrm{E}\right)$. The OSMOSE-GoG model simulates the trophic interactions of high trophic level species through their whole life cycles from eggs to adults at a time-step of a two-week period. For each time step, an individual can potentially feed on any prey depending on maximum and minimum predator/prey size ratios (Shin and Cury, 2004, 2001).

Eleven key species and one benthos group were explicitly represented in OSMOSEGoG: seven bony fish (i.e. Trachurus trachurus, Sardina pilchardus, Sardinella aurita, Engraulis encrasicolus, Diplodus annularis, Merluccius merluccius, Pagellus erythrinus), one cartilaginous fish (i.e. Mustelus mustelus), one cephalopod (i.e. Octopus vulgaris) and two crustaceans (i.e. Penaeus kerathurus, Metapenaeus monoceros). These species were selected according to their ecological and socioeconomic importance in the ecosystem of the Gulf of Gabes (Halouani et al., 2016). The main parameters of the model, namely, growth, reproduction, mortality and predation are presented in the appendix (Table A.1). The detailed description of model parameters and assumptions of OSMOSE-GoG can be found in our previously published paper (Halouani et al., 2016). 
In the framework of IndiSeas program (http://www.indiseas.org/) (Shin et al., 2012), several indicators were selected to perform comparative analyses across different exploited marine ecosystems. The main objective of this program is to select and analyze a set of ecosystem indicators to assess the ecosystem impacts of fishing in a context of changing environment and to provide decision support for fisheries management. A panel of scientific and strategic criteria was adopted to select a set of ecological indicators in support of ecosystem-based fisheries management. The selection of indicators was guided by six criteria listed in Table 1. At the end of the selection process, several types of ecological indicators (i.e biomass, landings, size and trophic level based) were retained to track the effects of fishing (Table 2). To be useful in fisheries decision-making, ecological indicators need to fulfill the three following performance criteria (Rice and Rochet, 2005):

- Sensitivity: Does the indicator respond significantly to fishing (i.e. smoothly, monotonically, and with high slope)?

- Specificity: The proportion of variance in the indicator attributed to fishing pressure compared to environmental forcing.

- Responsiveness: Does the indicator respond to changes in fishing pressure on short time scales?

Here, we contribute to evaluate the performance of selected indicators, by analyzing their sensitivity to fishing pressure. The reliability of the indicators regarding the specificity and responsiveness criteria was not evaluated. 


\begin{tabular}{|c|c|}
\hline Scientific criteria & Strategic criteria \\
\hline $\begin{array}{l}\text { Theory: indicators should have a firm } \\
\text { theoretical basis reflecting well-defined } \\
\text { ecological processes underlying fishing } \\
\text { pressure }\end{array}$ & $\begin{array}{l}\text { Tractability: indicators should be small } \\
\text { in number, tractable for a range of } \\
\text { ecosystems, and updated annually by } \\
\text { regional experts }\end{array}$ \\
\hline $\begin{array}{l}\text { Sensitivity: trends in indicators should } \\
\text { be sensitive to fishing pressure }\end{array}$ & $\begin{array}{l}\text { Public awareness: the meaning of the } \\
\text { indicators and their link to fishing should } \\
\text { be intuitively understood by the general } \\
\text { public }\end{array}$ \\
\hline $\begin{array}{l}\text { Measurability: indicators need to be } \\
\text { routinely measurable and have historical } \\
\text { data time-series available }\end{array}$ & $\begin{array}{l}\text { Coordination: the selection of } \\
\text { indicators must be linked to international } \\
\text { frameworks and projects to create } \\
\text { synergies (e.g. the CBD, European } \\
\text { MSFD, Sea Around Us Project) }\end{array}$ \\
\hline
\end{tabular}

Table 1: The list of criteria retained by the IndiSeas working group for the selection of ecological indicators (Shin et al., 2012)

\section{Scientific criteria}

Theory: indicators should have a firm

Table 2: List of indicators evaluated by OSMOSE-GoG

\begin{tabular}{|c|c|c|}
\hline Indicator & Calculation & Label \\
\hline $\begin{array}{c}\text { Mean length of fish in } \\
\text { the community }\end{array}$ & $\begin{array}{c}\bar{L}=\frac{\sum_{i} L_{i}}{N} \\
\text { Where } L_{i} \text { is the length of } \\
\text { individual } i \text { and } N \text { is the } \\
\text { number of individuals in the } \\
\text { community. }\end{array}$ & Mean length \\
\hline $\begin{array}{c}\text { Landings } \\
\text { (by species) }\end{array}$ & $Y_{S}$ & $\begin{array}{c}\text { "Y Octopus vulgaris", } \\
\text { "Y Merluccius merluccius", } \\
\text { "Y Pagellus erythrinus", } \\
\text { "Y Penaeus kerathurus", }\end{array}$ \\
\hline
\end{tabular}




\begin{tabular}{|c|c|c|}
\hline Indicator & Calculation & Label \\
\hline & & $\begin{array}{l}\text { "Y Metapenaeus monoceros", } \\
\text { "Y Trachurus trachurus", } \\
\text { "Y Sardina pilchardus", } \\
\text { "Y Sardinella aurita", } \\
\text { "Y Engraulis encrasicolus", } \\
\text { "Y Diplodus annularis", } \\
\text { "Y Mustelus mustelus" }\end{array}$ \\
\hline $\begin{array}{l}\text { Trophic level } \\
\text { (by species) }\end{array}$ & $\begin{array}{c}T L_{s}=1+\left(\frac{\sum_{i} Q_{i} \times T L_{i}}{\sum_{i} Q_{i}}\right) \\
\text { Where } T L_{s} \text { is the trophic level } \\
\text { of species } s, Q_{i} \text { the quantity } \\
\text { of prey } i \text { consumed by } \\
\text { species } s \text { and } T L_{i} \text { is the } \\
\text { trophic level of the prey } i .\end{array}$ & $\begin{array}{l}\text { "TL Octopus vulgaris", } \\
\text { "TL Merluccius merluccius", } \\
\text { "TL Pagellus erythrinus", } \\
\text { "TL Penaeus kerathurus", } \\
\text { "TL Metapenaeus monoceros", } \\
\text { "TL Trachurus trachurus", } \\
\text { "TL Sardina pilchardus", } \\
\text { "TL Sardinella aurita", } \\
\text { "TL Engraulis encrasicolus", } \\
\text { "TL Diplodus annularis", } \\
\text { "TL Mustelus mustelus" }\end{array}$ \\
\hline $\begin{array}{c}\text { Biomass } \\
\text { (by species) }\end{array}$ & $B$ & $\begin{array}{c}\text { "B Octopus vulgaris", } \\
\text { "B Merluccius merluccius", } \\
\text { "B Pagellus erythrinus", } \\
\text { "B Penaeus kerathurus", } \\
\text { "B Metapenaeus monoceros", } \\
\text { "B Trachurus trachurus", } \\
\text { "B Sardina pilchardus", } \\
\text { "B Sardinella aurita", } \\
\text { "B Engraulis encrasicolus", } \\
\text { "B Diplodus annularis", } \\
\text { "B Mustelus mustelus" }\end{array}$ \\
\hline $\begin{array}{l}\text { Large Fish Index: } \mathrm{LFI}_{20} \text {, } \\
\mathrm{LFI}_{30} \text { and } \mathrm{LFI}_{40} \\
\text { These indicators were } \\
\text { calculated by species } \\
\text { group (i.e. surveyed } \\
\text { species }{ }^{1} \text { (surv), } \\
\text { demersal species } \\
\text { (dem) and all species } \\
\text { (all)) }\end{array}$ & $\begin{array}{l}\text { The proportion of large fish } \\
\text { biomass in the assemblage. } \\
\qquad L F I_{40}=\frac{B_{40}}{B_{\text {Total }}} \\
\text { Where } B_{40} \text { is the biomass of } \\
\text { fish greater than } 40 \mathrm{~cm} \text { and } \\
B_{\text {Total }} \text { is the total biomass of } \\
\text { all fish in the sample. }\end{array}$ & $\begin{array}{l}\text { surv LFI } 20 \mathrm{~cm} \text {, } \\
\text { surv LFI } 30 \mathrm{~cm} \text {, } \\
\text { surv LFI } 40 \mathrm{~cm} \text {, } \\
\text { dem LFI } 20 \mathrm{~cm} \text {, } \\
\text { dem LFI } 30 \mathrm{~cm} \text {, } \\
\text { dem LFI } 40 \mathrm{~cm} \text {, } \\
\text { all LFI } 20 \mathrm{~cm} \text {, } \\
\text { all LFI } 30 \mathrm{~cm}, \\
\text { all LFI } 40 \mathrm{~cm}\end{array}$ \\
\hline
\end{tabular}

${ }^{1}$ surveyed species: species sampled by researchers during routine surveys (for more 195 details: http://www.indiseas.org/more-information) 
197

In order to test the sensitivity of the selected indicators and evaluate their consistency regardless of the fishing management plan, three simple contrasted fishing strategies were simulated. These fishing strategies were targeting the following groups: i/ "LTL strategy" targeting low trophic level species (e.g. forage species mainly feeding on plankton); ii/ "HTL strategy" targeting high trophic level species (predatory species including large demersal and large pelagic species) and iii/ "ALL strategy" targeting all exploited species in the fishery. For each fishing strategy, a multiplier $\lambda$ varying from 0 to 5 was applied to the fishing mortality corresponding to the maximum sustainable yield of the focus target species (FMSY). Non-focus species were still fished at their respective current fishing mortality ( $\left.F_{\text {curr }}\right)$.

$$
F_{\text {target species }}=\lambda \times F_{M S Y}
$$

Where $\lambda \in\{0,0.2,0.4,0.6,0.8,1,1.2,1.4,1.6,1.8,2,2.2,2.4,2.6,3,3.4,3.8,4.2,4.6,5\}$.

$$
F_{\text {non target species }}=F_{\text {curr }}
$$

Where $F_{c u r r}$ corresponds to the current fishing mortality of the non-target species.

The FMsy of each target species was estimated by reconstructing the Yield to F curve at equilibrium, while all other species were kept at their respective current fishing mortalities $F_{\text {curr. }}$ Given the stochastic nature of OSMOSE, 20 replicated runs per $\lambda$ value were simulated, then the outputs were averaged to estimate the ecological indicators of Table 2. To account for a spin-up time allowing the model to reach equilibrium, OSMOSE-GoG was run over 70 years of simulation. The average of each indicator was then calculated over the last 10 years of simulation. 
In order to compare the simulated indicators response objectively (129 response curves), three paradigms defining the desirable properties of an ecological indicator were scrutinized. The aim of these paradigms is to identify the most sensitive indicators to fishing pressure in the Gulf of Gabes. It is important to keep in mind that these paradigms assess partially the reliability of indicators since they do not evaluate their responsiveness and specificity.

$1^{\text {st }}$ Paradigm: The indicator value decreases with increasing fishing pressure.

This paradigm aims to facilitate the interpretation of indicators by managers especially when they have to use a set of different indicators to assess the status of marine ecosystems. Indeed, the decline of an indicator following an increase in fishing effort is considered as an intuitive result. In order to determine the trend of an indicator (positive or negative), a linear regression model was applied explaining the response of the indicators $(\mathrm{Y})$ as a function of the $\mathrm{F}_{\mathrm{MSY}}$ multiplier $(Y=a \cdot \lambda+b)$. Thus, when the slope $a<0$, the general trend is negative, which means that the indicator decreases with the increase of fishing pressure.

$2^{\text {nd }}$ paradigm: The indicator responds linearly to an increase in fishing pressure.

The coefficient of determination $\mathrm{R}^{2}$ of the linear regression model of each indicator was used to test the linearity of their responses to fishing pressure. This paradigm allows the identification of indicators that respond linearly to fishing in order to limit their misinterpretation. Thereby, a good indicator should have a high $\mathrm{R}^{2}$ (close to 1 ). 
$2413^{\text {rd }}$ paradigm: The consistency of the response of an indicator across fishing 242 strategies.

243 The aim is to identify indicators with similar responses across the three fishing 244 strategies. The objective is to simplify the monitoring of fishing impacts on the 245 ecosystem. For instance, after a possible change in fishing policy (targeting HTL or LTL species) managers would not be constrained to use a different set of indicators. In order to evaluate this property, the Spearman correlation coefficient was calculated between the three fishing strategies, two by two for each ecological indicator.

\section{Results and Discussion}

\subsection{Indicators' performance}

Several indicators were simulated to analyze their responses to a gradual increase of fishing pressure and to evaluate their respective performances. The response of the 54 indicators presented different shapes and trends depending on the fishing strategy and target species. These differences essentially lay in the magnitude of the response, the sign of the trend (positive or negative) and the linearity of indicators' responses. Due to the differences in units, the outputs of the simulations were centered and reduced to facilitate comparison between indicators (Fig. 3). The ALL strategy caused a general decline in trophic levels of all species with the increase of fishing mortalities, except for Octopus vulgaris and Mustelus mustelus. This result, in addition to the reduction of the proportion of large fish in the community (i.e surv.LFI.40.cm and dem.LFI.40.cm, see Fig. 3) can be seen as a manifestation of the phenomenon of "Fishing down marine food webs". However, our findings showed that, together with the potential of a gradual transition in species composition from 
high to low trophic level species under fishing pressure (Pauly et al., 1998), the intraspecific TL could also decrease in parallel. We also found that the application of a high trophic level strategy could lead to an increase in biomass of forage species (e.g Sardina pilchardus, Sardinella aurita and Engraulis encrasicolus) versus a decline in top predators biomass (e.g Mustelus mustelus, Merluccius merluccius). This result could be explained by the trophic cascade effects induced by the removal of predators when subjected to high fishing pressure (Daskalov, 2002; Halouani et al., 2015). Therefore, for the majority of species, especially the small pelagic fishes, we found that the response of their indicators changed according to the fishing strategy. A contrario, only the shark Mustelus mustelus presented the same negative trend in biomass regardless of the fishing strategy in response to an increase of fishing pressure. This is because Mustelus mustelus is at the top of the modelled foodweb with no direct competitors, so could be directly affected by fishing and/or indirectly by the decreasing of its preys' biomass when LTL or ALL trophic level strategies were applied. This suggests that apex predators may be considered as species flagship indicators to track the historical effects of fishing on the ecosystem. These results are consistent with previous findings showing the usefulness of the high trophic level indicator and the apex predator indicator to assess the environmental status of marine ecosystems for an ecosystem-based management of fisheries (Bourdaud et al., 2016). Overall, when the fishing strategy targeted all exploited species, most indicators were performing well showing a significant negative trend (except yield indicators) (Fig. 4A). However, only size-based indicators were appropriate for assessing the state of the ecosystem when there were changes in the fishing strategy. 


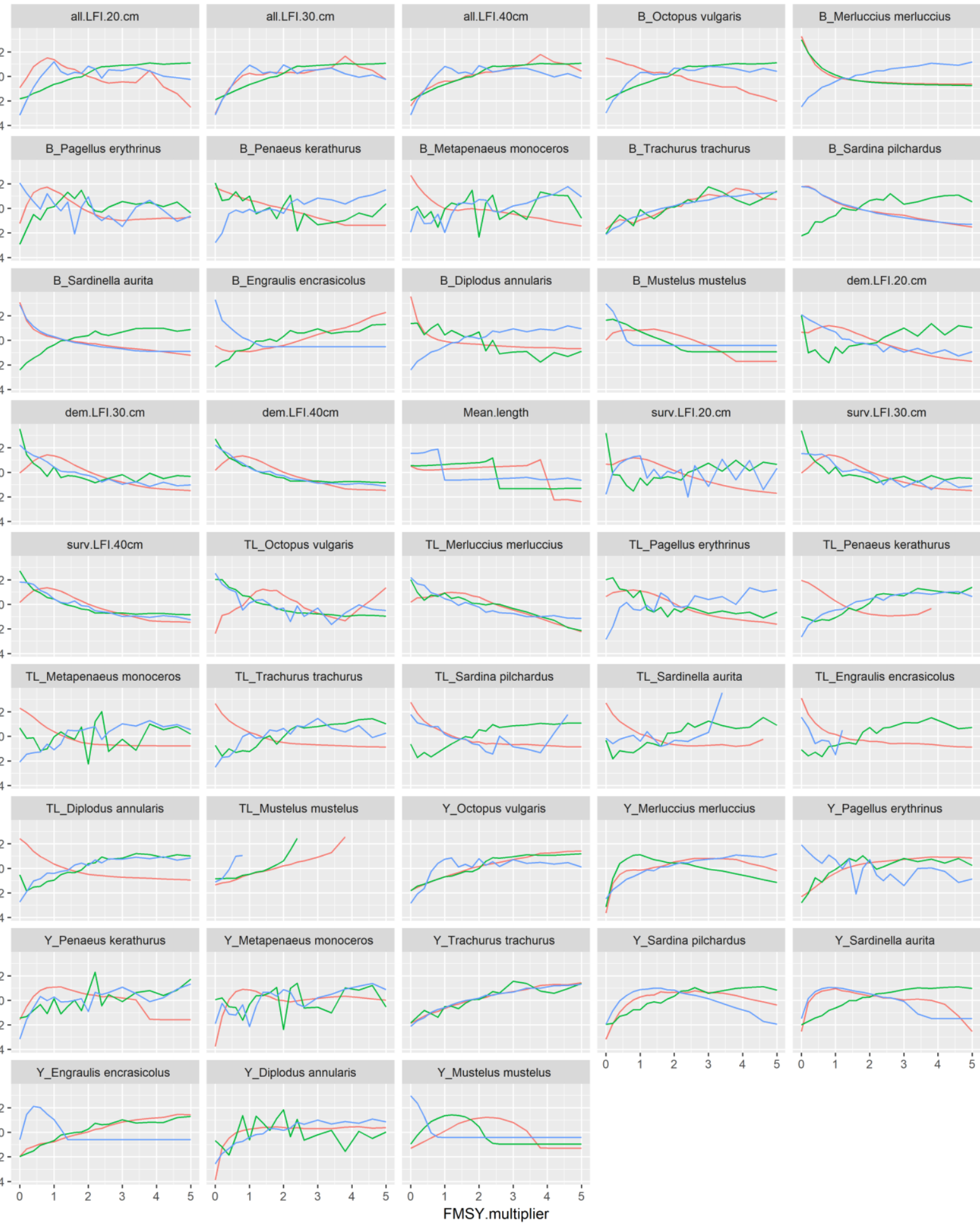

Fishing _ All exploited species strategy (ALL)

High Trophic Level species _ Low Trophic Level species (HTL)

(LTL)

Fig. 3. Response of the set of indicators simulated by OSMOSE-GoG as a function of the $F_{M S Y}$ multiplier for each fishing strategy (ALL, HTL, LTL). The values of all indicators were centered and reduced. 
A threshold value of 0.8 for the $R^{2}$ of the linear regression applied to the response of each indicator (indicator F FSY multiplier) was adopted to select the indicators with the most linear response. Results revealed that the presence of a significant linear trend depended on the fishing strategy. For example, the response of trophic level indicators was more linear with the HTL fishing strategy, in contrast with size-based indicators which displayed a more linear response when ALL or LTL strategies were applied (Fig. 4B). However, only the trophic level of top predators Mustelus mustelus and Merluccius merluccius exhibited a linear response for the three fishing strategies. Overall, the response of indicators was slightly more linear when the fishing strategy targeted all species.

The responses of the majority of indicators were not consistent across the different fishing strategies (Fig. 4C). Biomass indicators (especially for small pelagic fishes) displayed a negative correlation between high and low trophic levels fishing strategies. On the other hand, size-based indicators had the most consistent response across fishing strategies, compared to other types of indicators. ALL and HTL strategies were the two fishing strategies with the most similar impacts on the ecosystem: the correlation between indicators produced by ALL and HTL fishing strategies was higher than 0.8 for $35 \%$ of indicators.

This observation suggests that the response of the Gulf of Gabes ecosystem to fishing impacts was dependent on the status of top predators rather than on forage species. These results are in agreement with previous studies highlighting the ecological role of top predators in the stability of ecosystems (Heithaus et al., 2008). This result could also be explained by the high proportion of top predators in the Gulf of Gabes in comparison to other Mediterranean ecosystems (Halouani et al., 2015). 
319 The important biomass of high trophic level species (e.g. Octopus vulgaris, 320 Merluccius merluccius, Mustelus mustelus) could drive the intensity of top-down 321 control in the ecosystem and then its dynamics. Hence, the ALL and HTL strategies 322 exhibit similar pattern since they both target high trophic level species.

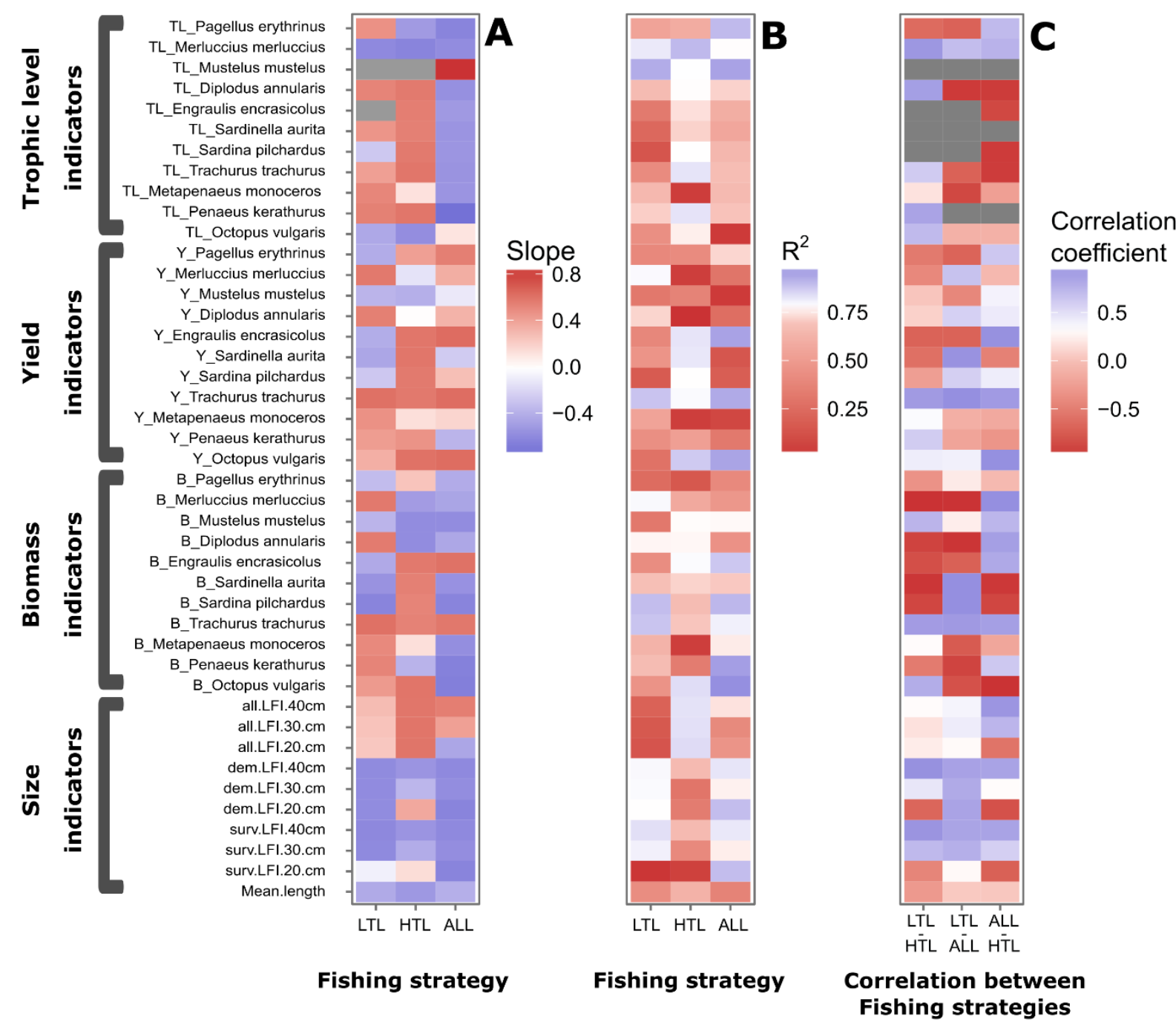

324 Fig. 4. Three facets of indicator responses to fishing, based on OSMOSE-GoG 325 simulations by fishing strategy: The trend (graph "A"), the linearity of the response 326 (graph "B") and the consistency of the responses between fishing strategies (graph "C"). In shaded areas, the indicator was not calculated because for some simulations, a species may no longer remain in the ecosystem due to a high increase in fishing mortality. 
331 The choice of appropriate indicators for fisheries management in the Gulf of Gabes consisted in identifying the ones which were the most sensitive to fishing pressure, in particular providing the best trade-off between the three facets of indicators' sensitivity: the rate of the response, the linearity of the response, and the consistency of the response across fishing strategies. Overall, simulation results showed that the majority of indicators had quite similar performance regarding the trend and the linearity of their responses. Regarding the consistency of the responses across different fishing strategies, size-based indicators were the most robust to track ecosystem effects of fishing (Fig. 5). A focus on size-based indicators revealed that the two indicators dem.LFI.40cm (the proportion of the biomass of demersal fish larger than $40 \mathrm{~cm}$ in the fish community) and surv.LFI. $40 \mathrm{~cm}$ (the proportion of the biomass of surveyed fish species larger than $40 \mathrm{~cm}$ in the fish community) derived from the Large Fish Indicator (LFI) were the most suitable to detect a change in the status of the resources in the Gulf of Gabes due to fishing pressure.

These results are in line with previous findings in the North Sea where the large fish indicator was developed as a size-based indicator of fish community status

347 (Shephard et al., 2011). Among the advantages of the LFI are its simplicity of 348 calculation, cost effectiveness and theoretical transparency which makes it 349 accessible to fishery managers and understandable by the public at large (Shephard 350 et al., 2011). This indicator has also been adopted as OSPAR's fish community 351 Ecological Quality Objective metric in the EU Marine Strategy Framework Directive 352 (2010/477/EU, 2010).

353 In this study, the performance of indicators was evaluated using the end-to-end model OSMOSE-GoG developed for the Gulf of Gabes ecosystem, therefore, the 
results of the simulations are not necessarily transposable to other ecosystems with different structure, functioning and environmental forcing. For example, an upwelling ecosystem, strongly driven by environmental conditions which act on the variability in fish recruitment, may require other types of indicators to assess the impact of fishing. Nevertheless, the results obtained for the Gulf of Gabes could still provide useful insights for indicators in other comparable ecosystems, especially in the Mediterranean Sea. This could be the case of the Adriatic Sea characterized by a large continental shelf and multi-gear and multispecies fisheries which are close to those found in the Gulf of Gabes (Coll et al., 2007; Halouani et al., 2015; Hattab et al., 2013).

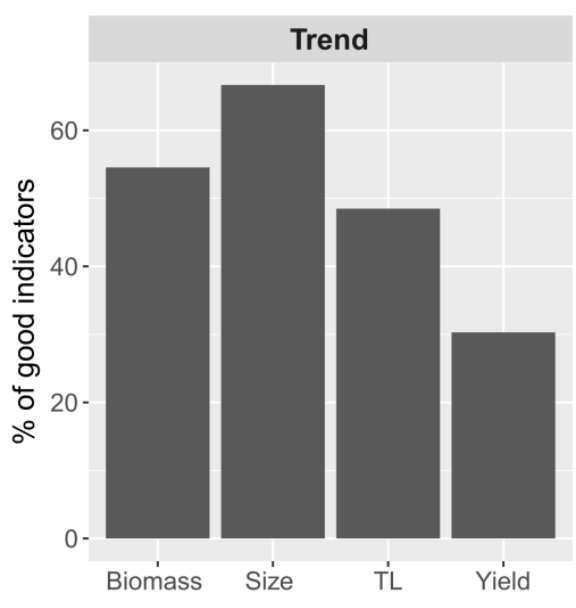

Fig. 5. Percentage of indicators that satisfy the criteria of each sensitivity facet. i/ Trend: negative slope, ii/ Linearity: $R^{2}$ of the linear regression (indicator $\sim F_{M S Y}$ multiplier) higher than 0.8 and iii/ Consistency: consistent response between the three fishing strategies. 
372 It appeared that ecological indicators were more efficient to reflect the ecosystem

373 effects of fishing in the Gulf of Gabes when the fishing strategy ALL was applied (Fig.

374 6). The results indicated that indicators are more likely to exhibit negative trends for the ALL strategy than for the selective high and low trophic level fishing strategies. Moreover, the results showed that the indicators' response was slightly more linear when the fishing strategy did not target high or low trophic levels specifically. This suggests that the ALL strategy, which is more similar to the debated Balanced Harvesting strategy (Froese et al., 2016; Garcia et al., 2012; Jacobsen et al., 2014), since less selective than the high and low trophic level fishing strategies, would lead to more predictable and less ambiguous response of indicators in the Gulf of Gabes. This could be explained by the fact that the effects of the trophic cascade are likely to be more pronounced when very selective fishing strategies are applied.

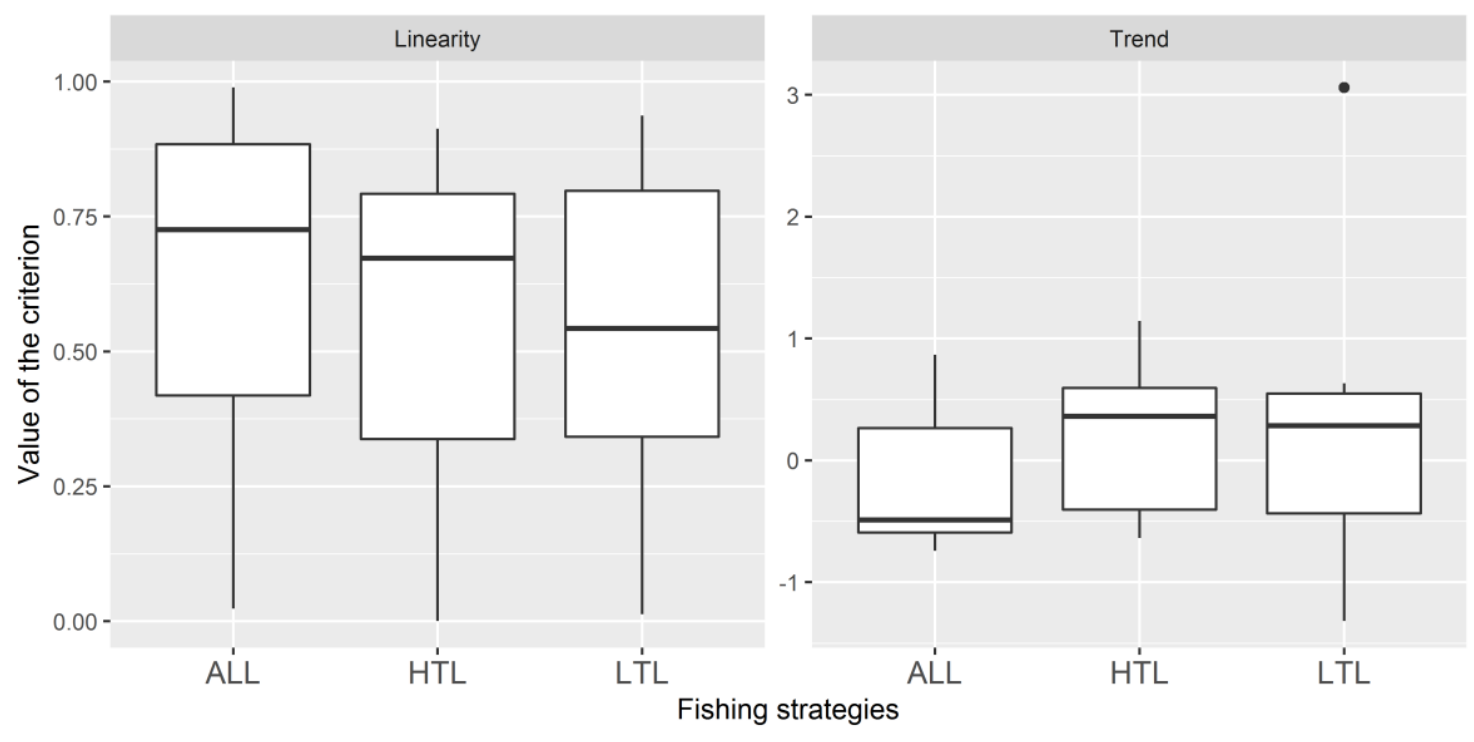

Fig. 6. The response of indicators by fishing strategy regarding the paradigms of linearity (high $\mathrm{R}^{2}$ corresponds to a linear response) and trend (negative slope corresponds to a decreasing trend). 
389 Using model simulations proved to be useful to understand the response of 390 ecological indicators to fishing pressure. However, there are some limitations 391 inherent to complexity of the ecosystem models. Indeed, a large amount of data from 392 different sources and different degree of uncertainties were used to implement the 393 end-to-end approach. For example, some input parameters were obtained from other 394 Mediterranean ecosystems (e.g. egg size, egg weight or relative fecundity). 395 Moreover, these parameters were measured or estimated in different periods. 396 Thereby, there is a need to perform a rigorous sensitivity analysis on the response of 397 simulated indicators to the OSMOSE-GoG parameter setting (e.g. the predator-prey 398 size ratios which drive the dynamics of the food web). Furthermore, the paradigms 399 proposed in this study only focused on the sensitivity criteria, while it is essential to 400 also consider the responsiveness and the specificity criteria to identify a set of 401 ecological indicators useful for ecosystem monitoring and management advice. 


\section{Next steps}

403

404

405

406

407

408

409

410

411

412

413

414

415

416

417

418

419

420

421

422

423

424

425

426

The indicators examined in this study were part of the panel of indicators selected by the IndiSeas working group (Coll et al. 2016; Shin et al. 2010) on the basis of criteria adapted from (Rice and Rochet, 2005) to evaluate the status of marine ecosystems in support of an ecosystem approach to fisheries: (i) the theoretical basis and the ecological processes underlying the ecological indicators, (ii) the measurability and existence of data time series, (iii) the general public awareness, and (iv) the sensitivity of indicators to fishing. The last criterion was clearly lacking supporting evidence and was difficult to quantify on the basis of observations only (Shin et al. 2012) so the use of ecosystem models and simulations is necessary to assess the performance of indicators in this regard. The present study is a step towards a better use of indicators in support of ecosystem-based management. However, since the status of the ecosystem is the result of multiple factors it becomes necessary to consider the environmental effects and the potential synergism or antagonism between climate forcing and fishing pressure (Fu et al., 2018; Planque et al., 2010; Travers-Trolet et al., 2014). In the context of multiple drivers potentially influencing marine ecosystems, there are few or no ecological indicators that can be considered exclusive to fishing (Shin et al., 2010). Hence there is a need to evaluate the specificity of indicators to fishing impacts. In the Gulf of Gabes, the size-based indicators, Dem.LFI.40.cm and surv.LFI.40.cm have proved to be the most sensitive to changes in fishing pressure. However, in case of contrasted environmental conditions, it is necessary to understand the capacity of these indicators to disentangle exploitation pressure from climate drivers so indicators are properly interpreted. Moreover, it is also important to consider the responsiveness of indicators to evaluate the rapidity of their responses to a change in fishing pressure. 
427 This is all the more important for managers and decision-makers who need to 428 evaluate the effectiveness of management plans on a short term basis (Rice and 429 Rochet, 2005). The evaluation of all of these components of indicators' performance could benefit from a comparative approach across ecosystems with contrasted 431 exploitation status and environmental forcing. The evaluation of the Large Fish 432 Indicator as the most sensitive ecosystem indicator to fishing in the Gulf of Gabes may help to provide a more efficient and focused monitoring of the fishery. In order to ensure the sustainability of marine resources, next step would be to identify LFl's thresholds to trigger actions to meet conservation and exploitation management objectives.

\section{Conclusion}

Developing an end-to-end model was a first step to improve our understanding of the trophic functioning of the food web and simulate fishing impacts across trophic levels in the Gulf of Gabes ecosystem. This first step has proved to be challenging, due to the complexity of model parameterization and some limitations related to the large amount of data from heterogeneous nature, sources and format integrated in the model. In this study, OSMOSE-GoG was used as a tool to test the performance of different ecological indicators in detecting changes in fishing pressure in order to provide support for decision-making. The results of this study suggested that Dem.LFI.40.cm and Surv.LFI.40.cm were the most suitable indicators to detect a change in status of the Gulf of Gabes due to fishing pressure. Nonetheless, it is 449 important to keep in mind that the Large Fish Indicator is appropriate to reflect exploitation impacts on the fish community structure; however, it is not a metric to evaluate ecosystem health. Thus, to fulfill the objectives of fisheries management of 
452 the Gulf of Gabes it is important not to consider exclusively the Large Fish Indicator

453 to monitor fishing impacts. The challenge of assessing the possible direct and indirect

454 fishing effects on the ecosystem requires the implementation of a set of ecological

455 indicators to enhance understanding of the management actions and their effects in

456 an ecosystem context.

457

458

\section{Acknowledgements}

459 This publication was made possible through support provided by the IRD-DPF PhD

460 fellowships program of the Institut de Recherche pour le Développement (IRD) for

$461 \mathrm{GH}$. It was also partly funded by the projects GAMBAS (JEAI IRD), BISTROMED

462 (ENVI-Med-MISTRALS), CHARMMED (Fondation TOTAL) and EMIBIOS (FRB,

463 contract no. APP-SCEN-2010-II). This is a contribution to the IndiSeas Working

464 Group, which, was co-funded by IOC-UNESCO (www.ioc-unesco.org), EuroMarine

465 (http://www.euromarinenetwork.eu), the European FP7 MEECE research project 466 (contract $n^{\circ} 212085$ ), the European Network of Excellence Eur-Oceans and the FRB

467 EMIBIOS project (contract $n^{\circ} 212085$ ). Finally, we would like to thank the anonymous 468 reviewers for their detailed comments and constructive suggestions on the 469 manuscript. 


\section{Appendices}

471 Table A.1. Summary of growth, reproduction, mortality and predation parameters for

472 each of the 11 species modelled in the OSMOSE-GoG model. $K, L_{\infty}$ and to: the von

473 Bertalanffy growth parameters; b: the exponent of the allometric length-weight

474 relationship; c: constant of proportionality of the allometric length-weight relationship;

475 Smat: size at maturity; $\varphi$ : relative fecundity; amax: longevity; Ms: mortality rate due to

476 predation from other species that are not explicitly considered in the model; F: annual

477 fishing mortality rate; Srec: size of recruitment.

\begin{tabular}{|c|c|c|c|c|c|c|c|c|c|c|c|c|c|}
\hline \multirow[b]{2}{*}{ Species } & \multicolumn{5}{|c|}{ Growth } & \multicolumn{2}{|c|}{ Reproduction } & \multicolumn{4}{|c|}{ Mortality } & \multicolumn{2}{|c|}{ Predation } \\
\hline & $\begin{array}{c}\mathrm{K} \\
\left(\mathrm{y}^{-1}\right)\end{array}$ & $\begin{array}{c}\mathrm{L}_{\infty} \\
(\mathrm{cm})\end{array}$ & $\begin{array}{l}\text { to } \\
\text { (y) }\end{array}$ & $b$ & $\begin{array}{c}\mathrm{c} \\
\left(\mathrm{g} \cdot \mathrm{cm}^{-3}\right)\end{array}$ & $\begin{array}{l}\text { Smat } \\
(\mathrm{cm})\end{array}$ & $\begin{array}{c}\varphi \\
\left(\text { egg. } g^{-1}\right)\end{array}$ & $\begin{array}{l}a \max \\
(y)\end{array}$ & $\begin{array}{l}\mathrm{Ms}_{\mathrm{s}} \\
\left(\mathrm{y}^{-1}\right)\end{array}$ & $\begin{array}{c}F \\
\left(y^{-1}\right)\end{array}$ & $\begin{array}{l}\text { Srec } \\
(\mathrm{cm})\end{array}$ & $\begin{array}{l}\text { Min } \\
\text { ratio }\end{array}$ & $\begin{array}{l}\text { Max } \\
\text { ratio }\end{array}$ \\
\hline $\begin{array}{l}\text { Octopus } \\
\text { vulgaris (sp1) }\end{array}$ & 1.24 & 159.01 & -0.06 & 3.66 & 7.41E-05 & 95.7 & 0.1 & 1.1 & 2.46 & 0.25 & 90 & 25 & 13 \\
\hline $\begin{array}{l}\text { Penaeus } \\
\text { kerathurus (sp2) }\end{array}$ & 0.69 & 18.03 & -0.30 & 3.14 & $3.90 \mathrm{E}-06$ & 12.7 & 7705 & 3 & 0.44 & 0.35 & 8 & 75 & 6 \\
\hline $\begin{array}{l}\text { Metapenaeus } \\
\text { monoceros (sp3) }\end{array}$ & 1.36 & 19.33 & 0.02 & 3.23 & 0.0045 & 12.2 & 9713 & 2.2 & 2.23 & 0.45 & 8 & 50 & 6 \\
\hline $\begin{array}{l}\text { Trachurus } \\
\text { trachurus (sp4) }\end{array}$ & 0.20 & 42.30 & -0.54 & 2.89 & 0.0114 & 21.0 & 1655 & 9 & 0.51 & 0.25 & 11 & 70 & 8 \\
\hline $\begin{array}{l}\text { Sardina } \\
\text { pilchardus (sp5) }\end{array}$ & 0.41 & 19.20 & -0.94 & 3.06 & 0.0065 & 12.5 & 360 & 5 & 0.60 & 0.35 & 9 & 300 & 8 \\
\hline $\begin{array}{l}\text { Sardinella } \\
\text { aurita (sp6) }\end{array}$ & 0.24 & 26.48 & -1.78 & 2.93 & 0.0061 & 14.3 & 337 & 7 & 0.50 & 0.25 & 11 & 300 & 8 \\
\hline $\begin{array}{l}\text { Engraulis } \\
\text { encrasicolus (sp7) }\end{array}$ & 0.36 & 17.19 & -1.01 & 3.16 & 0.0042 & 8.0 & 444.6 & 4 & 0.80 & 0.01 & 9 & 130 & 8 \\
\hline $\begin{array}{l}\text { Diplodus } \\
\text { annularis (sp8) }\end{array}$ & 0.16 & 22.64 & -2.00 & 3.09 & 0.0140 & 10.6 & 400 & 8 & 0.61 & 0.45 & 9 & 25 & 6 \\
\hline $\begin{array}{l}\text { Mustelus } \\
\text { mustelus (sp9) }\end{array}$ & 0.06 & 199.00 & -3.82 & 3.04 & 0.0043 & 117.2 & 0.01 & 20 & 0.47 & 0.08 & 50 & 14 & 7 \\
\hline $\begin{array}{l}\text { Merluccius } \\
\text { merluccius (sp10) }\end{array}$ & 0.19 & 102.85 & -0.79 & 3.12 & 0.0036 & 25.4 & 202 & 20 & 0.40 & 0.10 & 9 & 18 & 7 \\
\hline $\begin{array}{l}\text { Pagellus } \\
\text { erythrinus (sp11) }\end{array}$ & 0.14 & 35.79 & -1.63 & 2.71 & 0.0301 & 13.6 & 150 & 9 & 0.15 & 0.35 & 11 & 25 & 5 \\
\hline
\end{tabular}

478 


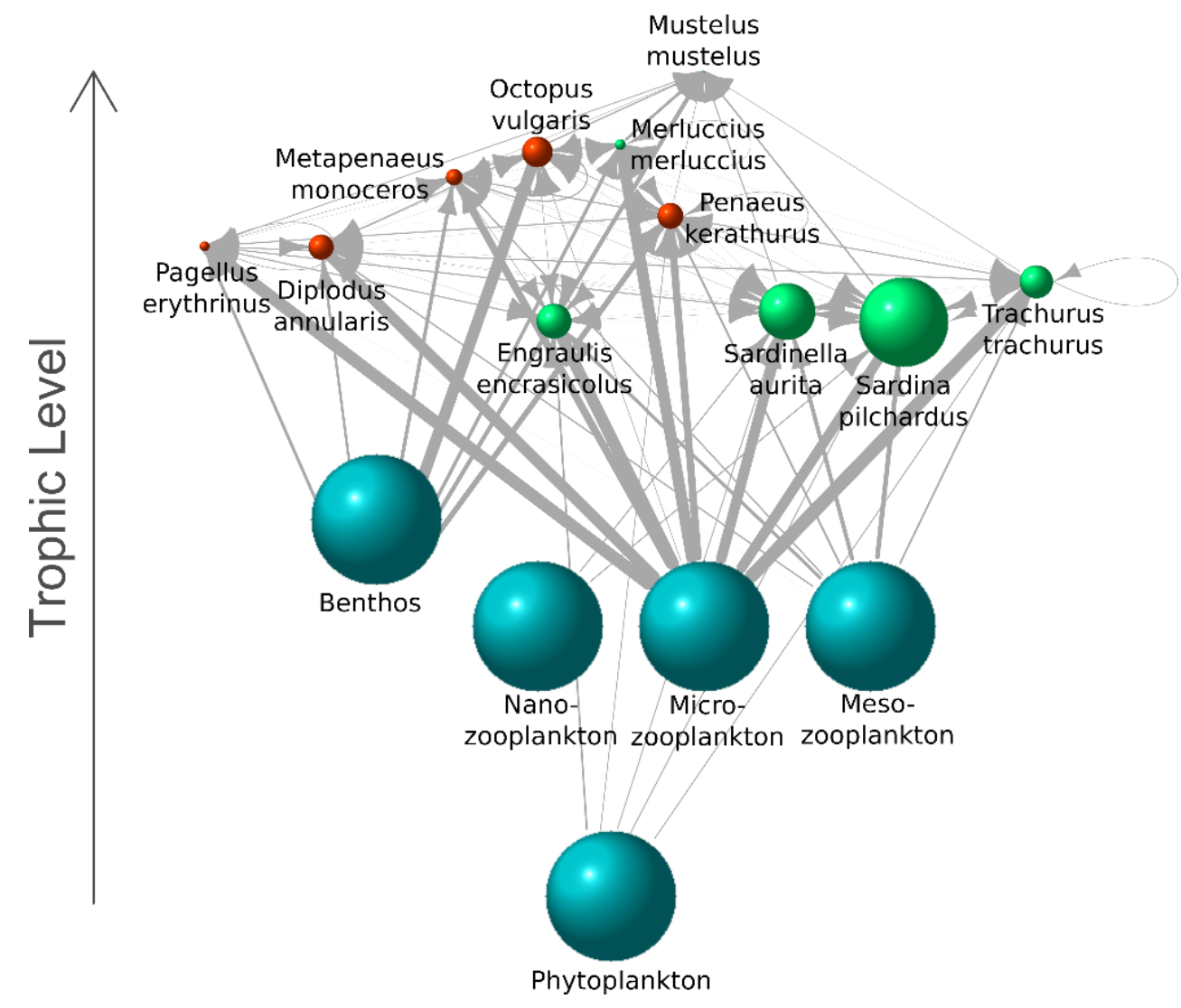

480 Fig. A.1. A schematic diagram of OSMOSE-GoG food web. Spheres represent 481 the modelled HTL species and LTL groups on a trophic scale. The volume of the 482 sphere is proportional to the species relative biomasses (except for LTL groups). 483 Solid arrows represent the trophic links between predators and their prey. The 484 thickness of the arrows corresponds to the proportion of prey species in the diet of 485 predator species. (Halouani et al., 2016) 


\section{References}

488

489

490

491

492

493

494

495

496

497

498

499

500

501

502

503

504

505

506

507

508

509

510

511

512

513

514

515

516

517

518

519

520

521

522

523

524

525

526

527

528

529

530

531

532

533

534

2010/477/EU: Commission Decision of 1 September 2010 on criteria and methodological standards on good environmental status of marine waters (notified under document C(2010) 5956) Text with EEA relevance, 2010. , OJ L.

Alekseenko, E., Raybaud, V., Espinasse, B., Carlotti, F., Queguiner, B., Thouvenin, B., Garreau, P., Baklouti, M., 2014. Seasonal dynamics and stoichiometry of the planktonic community in the NW Mediterranean Sea: a 3D modeling approach. Ocean Dyn. 64, 179-207. https://doi.org/10.1007/s10236-0130669-2

Ben Mustapha, K., Afli, A., 2007. Quelques traits de la biodiversité marine de Tunisie: Proposition d'aires de conservation et de gestion (MedSudMed Technical Documents No. 3). Rome, Italy.

Bourdaud, P., Gascuel, D., Bentorcha, A., Brind'Amour, A., 2016. New trophic indicators and target values for an ecosystem-based management of fisheries. Ecol. Indic. 61, 588-601. https://doi.org/10.1016/j.ecolind.2015.10.010

Coll, M., Santojanni, A., Palomera, I., Tudela, S., Arneri, E., 2007. An ecological model of the Northern and Central Adriatic Sea: Analysis of ecosystem structure and fishing impacts. J. Mar. Syst. 67, 119-154. https://doi.org/10.1016/j.jmarsys.2006.10.002

Coll, M., Steenbeek, J., Sole, J., Palomera, I., Christensen, V., 2016. Modelling the cumulative spatial-temporal effects of environmental drivers and fishing in a NW Mediterranean marine ecosystem. Ecol. Model. https://doi.org/10.1016/j.ecolmodel.2016.03.020

Daskalov, G.M., 2002. Overfishing drives a trophic cascade in the Black Sea. Mar. Ecol. Prog. Ser. 225, 53-63.

Drira, Z., Kmiha-Megdiche, S., Sahnoun, H., Hammami, A., Allouche, N., Tedetti, M., Ayadi, H., 2016. Assessment of anthropogenic inputs in the surface waters of the southern coastal area of Sfax during spring (Tunisia, Southern Mediterranean Sea). Mar. Pollut. Bull. https://doi.org/10.1016/j.marpolbul.2016.01.035

FAO (Ed.), 2016. Contributing to food security and nutrition for all, The state of world fisheries and aquaculture. Rome.

Froese, R., Walters, C., Pauly, D., Winker, H., Weyl, O.L.F., Demirel, N., Tsikliras, A.C., Holt, S.J., 2016. A critique of the balanced harvesting approach to fishing. ICES J. Mar. Sci. 73, 1640-1650. https://doi.org/10.1093/icesjms/fsv122

Fu, C., Travers-Trolet, M., Velez, L., Grüss, A., Bundy, A., Shannon, L.J., Fulton, E.A., Akoglu, E., Houle, J.E., Coll, M., Verley, P., Heymans, J.J., John, E., Shin, Y.-J., 2018. Risky business: The combined effects of fishing and changes in primary productivity on fish communities. Ecol. Model. 368, 265276. https://doi.org/10.1016/j.ecolmodel.2017.12.003

Garcia, S.M., 2003. The ecosystem approach to fisheries: issues, terminology, principles, institutional foundations, implementation and outlook. Food \& Agriculture Org.

Garcia, S.M., Kolding, J., Rice, J., Rochet, M.-J., Zhou, S., Arimoto, T., Beyer, J.E., Borges, L., Bundy, A., Dunn, D., Fulton, E.A., Hall, M., Heino, M., Law, R., Makino, M., Rijnsdorp, A.D., Simard, F., Smith, A.D.M., 2012. Reconsidering 
the Consequences of Selective Fisheries. Science 335, 1045-1047. https://doi.org/10.1126/science.1214594

Guyennon, A., Baklouti, M., Diaz, F., Palmieri, J., Beuvier, J., Lebaupin-Brossier, C., Arsouze, T., Béranger, K., Dutay, J.-C., Moutin, T., 2015. New insights into the organic carbon export in the Mediterranean Sea from 3-D modeling.

Biogeosciences 12, 7025-7046. https://doi.org/10.5194/bg-12-7025-2015

Halouani, G., Ben Rais Lasram, -->Frida, Shin, Y.-J., Velez, L., Verley, P., Hattab, T., Oliveros-Ramos, R., Diaz, F., Ménard, F., Baklouti, M., Guyennon, A., Romdhane, M.S., -->Le Loc $\square$ h, F., 2016. Modelling food web structure using an end-to-end approach in the coastal ecosystem of the Gulf of Gabes (Tunisia). Ecol. Model. 339, 45-57.

https://doi.org/10.1016/j.ecolmodel.2016.08.008

Halouani, G., Gascuel, D., Hattab, T., Lasram, F.B.R., Coll, M., Tsagarakis, K., Piroddi, C., Romdhane, M.S., Le Loc'h, F., 2015. Fishing impact in Mediterranean ecosystems: an EcoTroph modeling approach. J. Mar. Syst. 150, 22-33. https://doi.org/10.1016/j.jmarsys.2015.05.007

Hattab, T., Albouy, C., Ben Rais Lasram, F., Somot, S., Le Loc'h, F., Leprieur, F., 2014. Towards a better understanding of potential impacts of climate change on marine species distribution: a multiscale modelling approach. Glob. Ecol. Biogeogr. 23, 1417-1429. https://doi.org/10.1111/geb.12217

Hattab, T., Ben Rais Lasram, F., Albouy, C., Romdhane, M.S., Jarboui, O., Halouani, G., Cury, P., Le Loc'h, F., 2013. An ecosystem model of an exploited southern Mediterranean shelf region (Gulf of Gabes, Tunisia) and a comparison with other Mediterranean ecosystem model properties. J. Mar. Syst. 128, 159-174. https://doi.org/10.1016/j.jmarsys.2013.04.017

Hattour, A., Ben Mustapha, K., 2013. Le couvert végétal marin dans le golfe de Gabès: Cartographie et réseau de surveillance de l'herbier de Posidonie. Publication de l'Inst.Natn.Sci.Tech.Mer.

Heithaus, M.R., Frid, A., Wirsing, A.J., Worm, B., 2008. Predicting ecological consequences of marine top predator declines. Trends Ecol. Evol. 23, 202210. https://doi.org/10.1016/j.tree.2008.01.003

Jackson, J.B.C., Kirby, M.X., Berger, W.H., Bjorndal, K.A., Botsford, L.W., Bourque, B.J., Bradbury, R.H., Cooke, R., Erlandson, J., Estes, J.A., Hughes, T.P., Kidwell, S., Lange, C.B., Lenihan, H.S., Pandolfi, J.M., Peterson, C.H., Steneck, R.S., Tegner, M.J., Warner, R.R., 2001. Historical Overfishing and the Recent Collapse of Coastal Ecosystems. Science 293, 629-637. https://doi.org/10.1126/science.1059199

Jacobsen, N.S., Gislason, H., Andersen, K.H., 2014. The consequences of balanced harvesting of fish communities. Proc. R. Soc. B Biol. Sci. 281.

https://doi.org/10.1098/rspb.2013.2701

Lasram, F.B.R., Hattab, T., Halouani, G., Romdhane, M.S., Le Loc'h, F., 2015. Modeling of beta diversity in tunisian waters: predictions using generalized dissimilarity modeling and bioregionalisation using fuzzy clustering. PloS One 10, e0131728.

Papaconstantinou, C., Farrugio, H., 2000. Fisheries in the Mediterranean. Mediterr. Mar. Sci. 1, 5-18.

Pauly, D., Christensen, V., Dalsgaard, J., Froese, R., Torres, F., 1998. Fishing Down Marine Food Webs. Science 279, 860-863. https://doi.org/10.1126/science.279.5352.860 
Plagányi, É.E., Food, Nations, A.O. of the U., 2007. Models for an ecosystem approach to fisheries. Food and Agriculture Organization of the United Nations, Rome.

Planque, B., Fromentin, J.-M., Cury, P., Drinkwater, K.F., Jennings, S., Perry, R.I., Kifani, S., 2010. How does fishing alter marine populations and ecosystems sensitivity to climate? J. Mar. Syst., Impact of climate variability on marine ecosystems: A comparative approach 79, 403-417. https://doi.org/10.1016/j.jmarsys.2008.12.018

Rice, J., Rochet, M., 2005. A framework for selecting a suite of indicators for fisheries management. ICES J. Mar. Sci. 62, 516-527. https://doi.org/10.1016/j.icesjms.2005.01.003

Sasaki, T., Furukawa, T., Iwasaki, Y., Seto, M., Mori, A.S., 2015. Perspectives for ecosystem management based on ecosystem resilience and ecological thresholds against multiple and stochastic disturbances. Ecol. Indic. 57, 395408. https://doi.org/10.1016/j.ecolind.2015.05.019

Shephard, S., Reid, D.G., Greenstreet, S.P.R., 2011. Interpreting the large fish indicator for the Celtic Sea. ICES J. Mar. Sci. 68, 1963-1972. https://doi.org/10.1093/icesjms/fsr114

Shin, Y.-J., Bundy, A., Shannon, L.J., Blanchard, J.L., Chuenpagdee, R., Coll, M., Knight, B., Lynam, C., Piet, G., Richardson, A.J., Group, the I.W., 2012. Global in scope and regionally rich: an IndiSeas workshop helps shape the future of marine ecosystem indicators. Rev. Fish Biol. Fish. 22, 835-845. https://doi.org/10.1007/s11160-012-9252-z

Shin, Y.-J., Cury, P., 2004. Using an individual-based model of fish assemblages to study the response of size spectra to changes in fishing. Can. J. Fish. Aquat. Sci. 61, 414-431. https://doi.org/10.1139/f03-154

Shin, Y.-J., Cury, P., 2001. Exploring fish community dynamics through sizedependent trophic interactions using a spatialized individual-based model. Aquat. Living Resour. 14, 65-80.

Shin, Y.-J., Houle, J.E., Akoglu, E., Blanchard, J.L., Bundy, A., Coll, M., Demarcq, H., Fu, C., Fulton, E.A., Heymans, J.J., Salihoglu, B., Shannon, L., Sporcic, M., Velez, L., 2018. The specificity of marine ecological indicators to fishing in the face of environmental change: A multi-model evaluation. Ecol. Indic. 89, 317326. https://doi.org/10.1016/j.ecolind.2018.01.010

Shin, Y.-J., Shannon, L.J., Bundy, A., Coll, M., Aydin, K., Bez, N., Blanchard, J.L., Borges, M. de F., Diallo, I., Diaz, E., others, 2010. Using indicators for evaluating, comparing, and communicating the ecological status of exploited marine ecosystems. 2. Setting the scene. ICES J. Mar. Sci. 67, 692-716.

Travers, M., Shin, Y.-J., Shannon, L., Cury, P., 2006. Simulating and testing the sensitivity of ecosystem-based indicators to fishing in the southern Benguela ecosystem. Can. J. Fish. Aquat. Sci. 63, 943-956. https://doi.org/10.1139/f06003

Travers-Trolet, M., Shin, Y.-J., Shannon, L.J., Moloney, C.L., Field, J.G., 2014. Combined Fishing and Climate Forcing in the Southern Benguela Upwelling Ecosystem: An End-to-End Modelling Approach Reveals Dampened Effects. PLoS ONE 9, e94286. https://doi.org/10.1371/journal.pone.0094286

Worm, B., Barbier, E.B., Beaumont, N., Duffy, J.E., Folke, C., Halpern, B.S., Jackson, J.B.C., Lotze, H.K., Micheli, F., Palumbi, S.R., Sala, E., Selkoe, K.A., Stachowicz, J.J., Watson, R., 2006. Impacts of Biodiversity Loss on Ocean 
Ecosystem Services. Science 314, 787-790. https://doi.org/10.1126/science.1132294

Zucchetta, M., Venier, C., Taji, M.A., Mangin, A., Pastres, R., 2016. Modelling the spatial distribution of the seagrass Posidonia oceanica along the North African coast: Implications for the assessment of Good Environmental Status. Ecol. Indic. 61, Part 2, 1011-1023. https://doi.org/10.1016/j.ecolind.2015.10.059 